Article

\title{
On Democratization: Identity and Solidarity in Multicultural Societies
}

Shierwin A. Cabunilas

\begin{abstract}
How can one actually identify with people whose modes of being are substantially different from one's own? How can two groups engage in a dialogue who do not share certain fundamental values and concepts? To what extent does one identify? These concerns touch upon the sociological, political, and economic dimensions of a community. Accordingly, the task of political institutions is to provide adequate means of dealing with diverse identities. In this regard, I present a critical analysis of Charles Taylor's notion of multiculturalism and solidarity. ${ }^{1}$ While one can be sympathetic to his communitarian proposals, these proposals are apparently good wishes and less evident. I conclude the essay with my views on democratization.
\end{abstract}

Keywords: multiculturalism, political, economic solidarity, identity democratization

\section{Introduction}

$\mathrm{M}$

ulticulturalism has opened new possibilities for democratization. Societies are challenged, more than ever, to evaluate their perceptions and attitudes towards diversity. One concern in recent years is the problem of minority representation in the public sphere. In this paper, I advocate a comprehensive notion of minority groups: ethnocultural groups, new social movements, and migrants. ${ }^{2}$ Confronted with this concern,

${ }^{1}$ Adapted and revised from my MPhil thesis, Democratization of Society: Reflections on Charles Taylor's Theory of Democracy at the Catholic University of Leuven. I thank my promoter, Antoon Vandevelde for his instructive feedback and helpful supervision. My gratitude also to Hui Shuk Miu Lisa, Analissa dela Cruz, André Cloots, and Tim Heysse for their comments and suggestions, and to the anonymous referees of Kritike: An Online Journal of Philosophy.

2 Ethnocultural groups refers to groups of people inhabiting well-defined and sometimes overlapping territories, observing cultural practices, ancestral political-social structures, and claiming interests and conceptions of the good which often compete with the

(C) 2017 Shierwin A. Cabunilas

https://www.kritike.org/journal/issue 21/cabunilas december2017.pdf

ISSN 1908-7330

(cc) BY-NC-ND 
the task of political institutions is to provide adequate approaches of serving both the "recognition of difference and integration." 3 How should majority societies interact with minority groups who do not share their identity, history, and culture? Should laws and policies articulate the aspirations and identities of minorities in a majority society? The problem is relevant as it concerns the various facets of social structures, i.e., political, economic, and culture. In determining how best we can adequately address these concerns, I critically analyze Charles Taylor's notion of (1) multiculturalism and (2) political solidarity. ${ }^{4}$ In the conclusion, (3) I offer my views on democratization.

\section{Multiculturalism in a Democratic State}

Multiculturalism refers to a political orientation with the goal of "recognizing diversity, fostering integration, and producing/maintaining equality." 5 According to this view, multiculturalism can broaden our understanding of and justification for democracy as a suitable form of government that can adequately respond to multiculturalism. Some democratic states tend to be exclusively dominated by elite groups who collude to secure their interest at the expense of the society at large, or by a dominant voice that assimilates minorities according to its systems of relations. However, democracy, in its strict sense, is a system of government that recognizes the power of people to determine the direction of their social, economic, and political life through collective action and participative governance. ${ }^{6}$ Implicit in this conception of democracy is the sense of solidarity and recognition of diversity. However, these democratic ideals can only be achieved through a just system of policy-making. ${ }^{7}$ Consider a

mainstream society. The new social movements include, but are not limited to, environmental and gender movements. Minority groups also include internal and external migrants, who for various reasons such as economic or political move to other regions or states.

3 Charles Taylor, "Interculturalism or Multiculturalism," in Philosophy and Social Criticism 38 (2012), 416. Hereafter cited as "Interculturalism."

${ }^{4}$ This paper discusses the intellectual contribution of Charles Taylor's communitarian multiculturalism. There are other theoretical positions dealing on problems taken up in the essay but are not considered due to practical considerations. Nonetheless, Charles Taylor is one of the pioneers in the theorization of the politics of in multicultural societies.

${ }^{5}$ Taylor, "Interculturalism," 415. For the significant adaptation and accommodation of multicultural policies, see Irene Bloemraad, "The Debate Over Multiculturalism: Philosophy, Politics, and Policy," in Migration Policy Institute (2011), $<$ http://www.migrationinformation.org/Feature/display.cfm?ID=854>.

${ }^{6}$ Charles Taylor, Philosophical Arguments (USA: Harvard University Press, 1995), 273.

${ }^{7}$ For the statistical data on global immigration and public policies, see Will Kymlicka, "Multiculturalism: Success, Failure, and the Future," in Migration Policy Institute (February 2012),

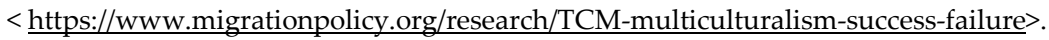


democratic society that does not observe civil rights. Such a society can be considered a dictatorial regime in a democracy's clothing. Because it tends to be inconsiderate of the rights of people of their fair share or just allocations of resources to pursue their conception of the good, it perpetuates injustice. Indeed, the absence of civil rights can bring more harm and cruelty by powerful forces. Civil rights must be secured because they serve as check and balance to political structures. Hence, the kind of government to advocate should be one that best serves equal political participation.

Contrary to the "hierarchical" notion of a political structure, a real democracy spouses a "horizontal" movement of political power. By 'horizontal,' I refer to a government where effective civic political participation is not only aspired for but also observed. The link between multiculturalism and democracy is evident in the democratic aspiration that "the sense of equal dignity is really shared by people who belong to functioning direct-access society together." 8 Hence, the challenge for a diverse society is to guarantee the basic ideals of democracy, namely: equality, civil rights, liberty, collective cooperation, and non-discrimination. ${ }^{9}$ Apparently, acknowledging the ethical underpinnings of a democratic society is a consequence of two significant moments at play in every modern society: identity struggle and recognition.

\section{A. Democratic Sphere as the Locus of Identity Struggle}

In its most basic concept, identity refers to a group of people's ascriptions of themselves and by others. It can have one or more of the following elements: language, cultural practices, traditions and beliefs, and/or norms and values. This is called the subjective aspect of identity. The objective aspect of identity, however, rests on how identity is conceived from the outside. According to this view, social actors are identified as belonging to a group by virtue of their "origin and background," that is, "sharing" and "playing the same game" or "criteria for evaluation and judgment." 10

${ }^{9}$ The United Nations strongly suggests that respect for cultural diversity can help forge a high-level solidarity. See UNESCO, "Universal Declaration on Cultural Diversity," in United Nations Human Rights - Office of the High Commissioner (2001), < $\underline{\text { http://www.ohchr.org/EN }}$ ProfessionalInterest/Pages/CulturalDiversity.aspx $>$. See also Commission for Social Development and Civil Society Forum, "Social Integration / Inclusion: Towards Societies of Solidarity and Mutuality," in United Nations - Department of Economic and Social Affairs, Division of Social Policy and Development (2009), <http://www.un.org/esa/socdev/csd/2009/documents/csf Ldeclaration.pdf $>$.

10 See Fredrik Barth, Introduction to Ethnic Groups and Boundaries: The Social Organization of Culture, ed. by Fredrik Barth (USA: Little, Brown and Company), 9-38.
}

${ }^{8}$ Charles Taylor, Dilemmas and Connections: Selected Essays (USA: Harvard University

(C) 2017 Shierwin A. Cabunilas

https://www.kritike.org/journal/issue 21/cabunilas december2017.pdf

ISSN 1908-7330

(c) BY-NC-ND 
In recent years, the struggle for recognition and assertion of identity has become a familiar story in every multicultural society. People ask whether or not they can still identify with the state, and whether or not its political structures promote and reflect the identity and welfare of the people. ${ }^{11}$ Taylor tends to admit that the reality of multiculturalism can be a threat to a harmonious existence because political interests between the state and groups of people can be so opposed to each other that it can yield "new set of issues which may deeply divide people." 12 He thinks that if these concerns are not adequately remedied, they will certainly pose "new obstacles to co-existence." 13 Consider a political institution that only favors the majority of the members of the society at the expense of minorities. Apparently, this can breed suspicion which can ultimately lead to political instability. An isolationist treatment by the state affects the relationship between groups of peoples towards each other.

Clearly, what is needed is a structural reform that is oriented to "a truly just and humane society." 14 But what does "a truly just and humane society" account for? From a communitarian perspective, a just and humane institution is one that advances substantive values and enhances the diversity of interests and cultural belonging by relating to the political state in different ways. Some might object that relating to the state in different ways cannot create long lasting and forward-looking opportunities for participative sociopolitical cooperation. However, if the communitarian's claim is correct, then it is necessary to align the political institution accordingly. Hence, an unjust political structure should be changed. Since the members of the society relate with the state in different ways, it is important to seriously consider the social context. It can be argued that a local province or region that determines its public affairs will not see public policies as impositions from external agents, but something that it can call its own. Moreover, since it makes its policies, it is more likely that they fit to respond to the local social context. This is called localization of power.

The localization of power sits well with Taylor's conception of "nested public sphere" which is aimed at decentralization and sharing of power. The localization of power advocates local assemblies, social movements, and local media among others. It fosters debates on local needs and issues that directly affect the interests of people with the aim of guiding

\footnotetext{
${ }^{11}$ Taylor, Dilemmas and Connections, 276.

${ }^{12} \mathrm{Ibid}, 132$.

${ }_{13}^{13} \mathrm{Ibid}$.

14 Charles Taylor, Philosophy and Human Sciences: Philosophical Papers 2 (USA: Cambridge University Press, 1985), 310. Hereafter cited as Philosophy and Human Sciences.
} 
public undertakings. ${ }^{15}$ Moreover, the debates can substantially influence the discussions and decisions at the national level. Localization of power serves as a check and balance to the preferred, yet sometimes elusive and invisible institutional state. Consequently, it enhances the sovereignty of the people. ${ }^{16}$ Taylor, however, is quick to acknowledge that this is not easy to achieve, considering widespread individualism and a distorted understanding of nationalism. ${ }^{17}$ Some might argue that it is only after firmly establishing the nation's dominance through public policies that an interest towards a fundamental ethic of equality and fair treatment of minorities will subsequently develop because by then the minority group is not anymore a threat to the dominant nation. For instance, Spinner-Halev claims that "when the ascendance of a nation is secure, it can turn to treating its minority citizens well."18 I tend to concur that in any political institution, the dominant group's interests always take precedence. There are underlying negative implications that should be taken into consideration. It might echo a wrong signal which can mean two things. First, the dominant group has a right to exclude the minority in policy decision making. Second, it relaxes the horrors of violent nationalism, such as the Holocaust in WWII, the genocide in the multicultural country Bosnia-Herzegovina by the Serbs against the Muslim Albanians, and in Darfur, Sudan among others.

However, Taylor argues that any "holistic" advocacy should "give higher priority to community life" and not merely to the interest of a particular dominant group. ${ }^{19} \mathrm{~A}$ political institution rightly responds to such a view when it prioritizes the needs of the community and not of a particular group's interest. As this happens, alterity and difference become important aspects in weaving policies that extend sufficient respect to self-worth. Nonetheless, Taylor warns that the democratization of society is stymied "when a group or cultural community feels unrecognized by the larger society, and so becomes less willing to function on a basis of common understanding with the majority." 20

${ }^{15}$ Charles Taylor, Modern Social Imaginaries (Durham and London: Duke University Press, 2004), 89.

16 Taylor, Philosophical Arguments, 279.

${ }^{17}$ Ibid., 281.

${ }^{18}$ Jeff Spinner-Halev, "Democracy, Solidarity and Post-nationalism," in Political Studies 56 (2008), 615.

${ }^{19}$ Taylor, Philosophical Arguments, 182.

${ }^{20} \mathrm{Ibid}$., 281.

(C) 2017 Shierwin A. Cabunilas

https://www.kritike.org/journal/issue 21/cabunilas december2017.pdf

ISSN 1908-7330

(c) BY-NC-ND 


\section{B. Recognition of Identity in Modern Society}

It seems that identity is at stake in modern society. ${ }^{21}$ Minority groups, for instance, are confronted with the thought that they might hardly be able to negotiate their concerns and interests with the dominant society. An experience of exclusion will always be a phenomenon to confront with, especially when the minority feels frustrated as the dominant group imposes its interest upon them. It is likely that among dominant groups, "strong national sentiments" will be asserted. The presence of the minority can be considered a threat to their established norms and practices thus fortifying nationalistic tendencies. As Taylor concurs, the "identity [of the minority] is vulnerable to nonrecognition ... by the members of the dominant societies," because the presence of the minority seems to threaten the majority. ${ }^{22}$

Apparently, the skepticism, according to which the presence and role of a minority in the flourishing of the society can preclude an affirmative collaboration and integration of diverse views is counter-intuitive and an overstatement. On the contrary, it seems advantageous for diverse societies to collaborate for a common goal. And since a person's identity is evolving and not static, one can continue to grow by relating to others. Learning to integrate with diversity and alterity through conversation and mutual understanding can help a society adequately advance the needs of its members than otherwise conceived. However, one cannot simply fault those groups that have become less willing to recognize diversity and hard on securing their borders when it is clearly established that threats to national security or welfare of the people are at stake.

Nonetheless, the recognition of diversity and alterity does not merely advance a more hospitable environment. It is also necessary for the formation of a person's identity. Acknowledging the "other" can broaden one's understanding of oneself, that is, one's conception of identity. In every culture, there are good things which can enhance life, but there are also elements that can demean and depreciate one's self-worth for which political institutions must be vigilant. Nonetheless, it seems that in a horizontal relation diverse groups can learn from each other what it means to live by respecting self-worth. ${ }^{23}$ This is the case, for example, among peers in an academic community, family members and friends where a respectful exchange of diverse views can enhance both personal and social growth.

\footnotetext{
${ }^{21}$ Taylor, Dilemmas and Connections, 277.

22 Ibid., 278.

${ }^{23}$ Taylor, Dilemmas and Connections, 277; Charles Taylor, Human Agency and Language: Philosophical Papers 1 (USA: Cambridge University Press, 1985), 88. Hereafter cited as Human Agency and Language.
}

(c) 2017 Shierwin A. Cabunilas https://www.kritike.org/journal/issue 21/cabunilas december2017.pdf ISSN 1908-7330 
Apparently, a genuine encounter with diversity broadens one's conception of identity because a single brand of identity as a criterion for any social, political, and economic relations is not sufficient. ${ }^{24}$ Through sincere "comparisons and contrasts" of diverse views, cooperation on various aspects of the society can be enhanced. ${ }^{25}$ Consequently, Taylor believes that "we ... liberate the others and 'let them be' when we can identify and articulate a contrast between their understanding and ours, thereby ceasing" to regard them from a one-sided perspective. ${ }^{26}$ The opportunity to learn and to work with the "other" will diminish by clinging on a narrow and restricted conception of identity. However, sincere recognition through dialogue allows one to broaden his/her understanding of the "other," thus affirming that no one holds the absolute mark of a superior identity, Taylor claims. ${ }^{27}$ The social nature of a person points to the reality that values and aspirations are something that people discover together, and that no one has the monopoly of the truth. Of course, every identity seems to have its strengths and flaws. Nonetheless, recognizing diversity opens the possibility for people to appreciate each other's uniqueness, to complement each other's strength, and to supply each other's paucity.

The reality of multiculturality calls for a sense of dialogue with alterity and diversity by breaking through one's fixated attitude which encloses the self from establishing a mutual collaboration with others. The inability to recognize diversity "can inflict harm, can be a form of oppression, imprisoning someone in a false, distorted, and reduced mode of being." 28 However, a horizontal relationship, which ensues from trusting and understanding, fortifies the claim that people can co-exist not merely because they exhibit different social ways and features but also because their differences are sources of mutual enrichment. In political matters, for example, the acknowledgment of diversity responds to a fundamental assumption of democracy, that is, political equality wherein "various groups,

24 Charles Taylor, "Solidarity in a Pluralist Age," in Project Syndicate (2010) $<$ http://www.project-syndicate.org/commentary/solidarity-in-a-pluralist-age $>$. Hereafter cited as "Solidarity."

${ }^{25}$ Elsewhere, Taylor notes that through dialogue, which facilitates an encounter and better understanding of the "other," a person can re-orient his/her views, goals and values towards the good of the society. See Taylor, "The Other and Ourselves: Is Multiculturalism Inherently Relativists?" in Project Syndicate (19 July 2002), < https://www.projectsyndicate.org/commentary/the-other-and-ourselves--is-multi-culturalism-inherentlyrelativist?barrier=accessreg $>$.

${ }^{26}$ Taylor, Philosophical Arguments, 150.

${ }^{27}$ Dialogue commences "from the fact that we are all less satisfied and dogmatic in our possession of the truth; that we are all therefore in some way researchers." See Charles Taylor, The Pattern of Politics (Toronto: The Canadian Publishers, 1970), 124.

${ }_{28}$ Charles Taylor, "The Politics of Recognition," in Multiculturalism: Examining the Politics of Recognition, ed. by Amy Gutmann (Princeton: Princeton University Press, 1994), 25.

(C) 2017 Shierwin A. Cabunilas

https://www.kritike.org/journal/issue 21/cabunilas december2017.pdf

ISSN 1908-7330

(cc) BY-NC-ND 
types, and classes of citizens have been given a genuine hearing and were able to have an impact on the debate." 29 Some demands can be too much for the government to discharge or allocate. Minority groups might not be provided of all that they ask to satisfy their needs and interests, but they "can have a sense that they are heard because they know themselves to be valued in a certain way, even when some particular demands are not met." 30

Furthermore, an "other-understanding" disposition gives credence to the "equal worth of cultures." This does not mean sameness of cultures, rather, it claims the view that "all human cultures that have animated the whole of societies over some considerable stretch of time have something important to say to all human beings." 31 Cultures have an epistemic value that can guide political institutions in responding adequately to societal concerns. They are sources of knowledge. Their epistemic value can be appropriated in understanding and in responding to social, economic, cultural, and political concerns that affect society. One can think, for example, of a grassroots-based conflict resolution. Accordingly, if "the search for recognition is, properly understood, a demand for reciprocal recognition, within the life of the community," 32 then it is inevitable that a functioning democratic society should render respect to the equal worth of every identity according to which an inclusive toleration of diversity is a virtue. This includes language or mother tongue, customs and tradition, religion, conceptions of the good, among others which do not inflict harm or disrupt the functions of political institutions. Accordingly, unjust institutions and practices (e.g., slavery, clitoridectomy, forced marriage, etc.) that disadvantage weak members of society should be abolished because ultimately, "the true goal of the search for recognition remains community." 33 The recognition of diversity enriches community life and highlights the very reason why people bond together. ${ }^{34}$ Recognition of diversity and alterity can fill what might be lacking in others and enriches what is already available in them. This view advances more tolerant and sympathetic societies.

The above views are not immune from objections, however. First, they seem ideal and seem to bear good wishes, but actual situations suggest otherwise. Multicultural communities are so complex to manage. To say that recognition and inclusion demand "identification" with others is rather easy. How can one identify with peoples whose modes of being are substantially

\footnotetext{
29 Taylor, Philosophical Arguments, 276.

${ }^{30}$ Ibid., 277.

${ }^{31}$ Taylor, "The Politics of Recognition," 66.

32 Taylor, Human Agency and Language, 88.

${ }^{33} \mathrm{Ibid}$.

${ }^{34}$ Charles Taylor, "The Dynamics of Democratic Exclusion," in Journal of Democracy 9:4
} (1998), 153

(c) 2017 Shierwin A. Cabunilas https://www.kritike.org/journal/issue 21/cabunilas december2017.pdf ISSN 1908-7330 
different from one's own, and how far should one identify? How can two groups engage in dialogue who do not share certain fundamental values and concepts? Indeed, there are competing choices to be evaluated and compromises to be made, and usually these are emotionally charged. Some might argue that identification with diversity should be tempered by public policies. While democracy guarantees the fundamental ethics of "human rights, equality, and non-discrimination," migrants have the responsibility to understand the political milieu and culture of the host society that welcomed them. This entails that migrants should adhere to the laws or policies inscribed in the constitution. In the first place, to be granted entry to a host state, in principle, is a privilege. It is never, legally speaking, a right. Nonetheless, active participation in public affairs becomes more accessible when one becomes a citizen. The obligation to abide by the constitution and laws of a receiving country, however, does not mean renunciation of one's own cultural heritage. A migrant might learn the language and some other practices of the host state, but citizenship does not mean total assimilation to the culture of the majority group. For every migrant, the important issue, in my view, is whether the basic democratic ideals are being observed, or to demand from the government where they are not accessible within reach.

Second, some might claim that multiculturalism, while it is good for society, is more complicated than a mono-cultural society. In other words, the imposition of a majority culture in a multicultural society has more farreaching results in terms of effectivity and efficiency because there are no differentiated rights but only one law that equalizes and neutralizes all groups. Viewed from another perspective, mono-culturalism can be used to argue for maintaining the stability of the social security of the citizens. For example, in some multicultural countries migrants are regarded as economic, social security, welfare competitors. So, to get rid of competitors, the state can set a higher bar on immigration policies. In doing so, the political state will deter the influx of migrants and in turn secure the welfare of the citizens. However, whether setting the bar higher is democratic at all, and whether it can maintain internal social cohesion, seems doubtful because contestations and dissents are always part of the dynamics of social relations.

Third, others assume that it seems difficult to advocate a balance between cultural diversity and political identity. Emphasizing one over the other can resort to political disintegration. A deficiency in political identity among peoples of diverse cultures can also weaken the point of living together. The lack of political identification can spring misunderstanding and violence, leading to a serious threat to social harmony. An example of this is the Southern Philippines where several Filipino Muslim leaders and representatives in the island of Mindanao think that it is better for them to live as an independent state because of their unique cultural, linguistic and

(C) 2017 Shierwin A. Cabunilas

https://www.kritike.org/journal/issue 21/cabunilas december2017.pdf

ISSN 1908-7330

(c) $)$ BY-NC-ND 
historical identity. This view, of course, challenges national integrity. It seems that where political identity is lacking, among diverse and different groups of peoples, there is no point of living together. Secession can be a worthwhile option. Having a separate state might give them an optimal power to decide and to govern their own affairs, just like in federal states. Nonetheless, the extent to which the stability of a political institution remains intact would largely depend on the solidarity of its members with the political state. But this needs forward-looking institutional and legislative reforms that best respond to the problem of minority representation in the public sphere.

\section{Solidarity in Multicultural Society}

Modern societies are a constellation of various groups whose identity needs recognition. The fact of diversity enjoins us to open the door of our "closely-knit, strongly-bonded communities" in order to build a sense of solidarity, belonging with the other members of society. Solidarity is crucial for the well-being of society because it can be a preventive measure to any socio-political fragmentation. ${ }^{35}$ Solidarity transcends the boundaries of one's religious, cultural and linguistic affiliations. How far should the practice of solidarity as a "common allegiance to the political community" 36 be enforced or limited to a multicultural society? An analysis of two forms of solidarity, namely, patriotic and socio-economic, I believe, can shed light upon this concern.

\section{A. Patriotic Solidarity}

Taylor claims that "the modern democratic state needs a healthy degree of what used to be called "patriotism." 37 Patriotism refers to the strong identification of the people with the political state. It reflects a common enterprise aimed at building a stable and cohesive society. This view implies two claims: Patriotic solidarity is (1) a response to self-absorption and (2) grounded on a collective identity.

The former suggests that patriotism counterbalances the problem of self-absorption in which a person tends to care less of others and to disengage from public affairs. There is no easy way for solidaristic patriotism to prosper. Apparently, a suitable political institution and workable programs can glue people together, breaking through the barriers of race, language, and color. Sincere recognition of equal worth can be a source of this social glue because (2009), 49.

${ }^{35}$ Nicholas H. Smith and Arto Laitinen, "Taylor on Solidarity," in Thesis Eleven 99

36 Taylor, “The Dynamics of Democratic Exclusion," 144.

37 Taylor, Dilemmas and Connections, 90; Taylor, Philosophical Arguments, 188.

(c) 2017 Shierwin A. Cabunilas

https://www.kritike.org/journal/issue 21/cabunilas december2017.pdf

ISSN 1908-7330 
it opens the path where different meanings of people meet and integrate. This approach is hoped to motivate diverse groups into a "collective action." 38 Hence, despite the different meanings claimed by diverse groups, they can still mutually work together to achieve a common purpose.

The latter claims that patriotism rests on a collective identity which can guarantee social cohesion. In the absence or lack of a collective identification, the state is susceptible to disintegration. Seemingly, differences can turn into strengths when people are motivated by a common goal. By upholding the same values and sharing the same interests, peoples' ties tend to be intact. Thus, they are also willing to fight for their sources of identity and belonging when threatened.

While collective identity is a motivating factor in the formation of patriotic ideals, it tends to exclude and assimilate one group or another. Political institutions can lend themselves to exclusivism when they emphasize what Taylor calls "homogenization of identity." ${ }^{39}$ Homogeneity is the eradication of diversity which also weakens the capacity of people to live together despite their differences. Homogenization is expressed concretely in terms of ethnocentric tendencies which intentionally negates the value of diversity and otherness because the "other" is categorized as an inferior species. However, to say that a majority culture becomes the norm upon which others should be measured implies that some groups cannot be part of a given society. If this is correct, those who cannot meet the requirement might have no place in the overall interest of the state.

Apparently, when homogenization of identity becomes the norm, it may give rise to what I call "solidaristic contestations" according to which collective opposition are introduced in response to the tendency of powerful forces in subordinating the "other." Hence, solidarity, albeit in a contestatory way, can also take place when the concerns of minority groups are excluded from the overall interest of the political state. If patriotic solidarity is a necessary assurance for maintaining a stable society and social cohesion, how should "homogenization of identity" be remedied?

Two things come to mind. First, patriotic sentiments can emerge by changing one's distorted conception of the "other." The key element here is political equality. According to this view, the "other" should be treated fairly, that is, with equal dignity and equal worth. For Taylor, the "other" should not be treated as "them" - a distant and withdrawn social agent whose primary function is to provide the satisfaction of interest-because they are

\footnotetext{
${ }^{38}$ Charles Taylor and Slawomir Sierakowski, "The de-politicization of politics," in Eurozine (10 November 2011) <http://www.eurozine.com/articles/2011-11-10-sierakowskien.html>.

${ }^{39}$ Taylor, Dilemmas and Connections, 90.
}

(C) 2017 Shierwin A. Cabunilas

https://www.kritike.org/journal/issue 21/cabunilas december2017.pdf

ISSN 1908-7330

(c) BY-NC-ND 
"potential partners" 40 in democratic political deliberations. Policy decisions somehow reflect the aspiration and identity of deliberative participants. Consequently, it is a significant loss for the political state to regard inadequately the voices of people of different race, gender, color, and linguistic affiliation. Hence, there can be no real solidaristic patriotism until we acknowledge our own identity as one among the many other possible forms.

Second, solidarity with minorities is expressed not merely by being aware of their needs and interests, but also by recognizing their role in the political, economic, and cultural levels. ${ }^{41}$ Politically, while it is the right of citizens to decide which policies to implement, minority interests should also be considered. Economically, migrants, for example, can boost economic progress by utilizing their own knowledge and skills. Culturally, they can enrich and broaden one's perspectives. They can contribute substantially in the practice of democracy because they open various opportunities that nurture a quality and meaningful life. As such, a solidaristic patriotism prospers when the dignity of every individual is equally respected. However, a fragmented citizenry persists when contempt, antagonism, and suspicion are not mitigated.

With the above contentions, I argue that political solidarity is more than emphasizing "my culture" or "my citizenship." Rather, it is a question of peoples' conscientious political participation in the society. Because of the recognition of "equal worth," diverse groups can work together for common goals. It should be noted that some citizens might only be interested in what the state can favorably do for them, but are indifferent to public affairs. Those considered "others," however, can solicitously contribute to the good of the state in various ways. I think, for instance, of the Filipinos in Singapore. ${ }^{42}$ On 19 April 2014, Filipino organizers of the 12 June 2014 Philippine Independence Day celebration were harassed. Some Singaporeans slammed the proposed activity. Lee Hsein Loong, the Prime Minister of Singapore, "appalled by the harassment," apologized, saying that it is "a disgrace to Singapore" and "many sensible Singaporeans condemn this thuggish behavior." 43 He enjoined that Singaporeans "must treat people in Singapore the way [they expect] to be treated overseas," and to show that "[Singaporeans] are generous of spirit and welcome visitors into [their]

${ }^{40}$ Taylor, "The Dynamics of Democratic Exclusion," 144, 146.

41 Taylor Dilemmas and Connections, 130.

42 In the year 2011, there are close to 150,000 overseas Filipino workers behind the economic progress of Singapore. See "Compendium of OFW Statistics (2005-2011)," in Philippine Overseas Employment Agency, < http://www.poea.gov.ph/ofwstat/compendium/2011.pdf>.

${ }^{43}$ Camila Diola, "Singapore Leader defends Pinoys, labels 'spammers' a disgrace," in Philippine Star Global (21 April 2014), < http://www.philstar.com/headlines/2014/04/21/1314411 singapore-leader-defends-pinoys-labels-spammers-disgrace $>$.

(c) 2017 Shierwin A. Cabunilas

https://www.kritike.org/journal/issue 21/cabunilas december2017.pdf

ISSN 1908-7330

(cc) BY-NC-ND 


\section{ON DEMOCRATIZATION}

midst, even as [they] manage the foreign population [in Singapore]." ${ }^{44}$ It might be the case that there have been some problems associated with the presence of migrant groups. Some of them could have truly disturbed the security and peace that dominant groups enjoy. But these incidents cannot justify acts of discriminations or exclusions. Apparently, the hope for a better society is still through sincere recognition.

\section{B. Solidarity in Socio-economic Welfare}

Economic preoccupation can be an obstacle to solidarity and democratic ideals. When we think of the economy in terms of enriching oneself without due regard for the common interest, we trespass some essential components of justice, namely, distribution of resources and social welfare. An economy that is dissociated from social responsibility will only be concerned with profiteering. As a result, inequality abounds when people think only of what they can gain, like capitalism which refers to an economic system often operated by private individuals whose interest is to increase profit and to exploit the vulnerability of weaker people. ${ }^{45}$ A capitalist can "unilaterally raise his income at the expense of consumers without any compensating increase in their welfare." 46 Capitalism is considered a socioeconomic malpractice because it steals and siphons the interests and needs of a person and the community.

Consider an ancestral domain that is taken over by transnational companies in the name of economic progress. It is likely that local economic sustainability and the welfare of cultural groups in the area are placed at risk, which usually happens. In cases like these, there is no such thing as equal opportunity for everyone, but rather inequality and injustice along economic and even political lines. Because capitalism seems interested merely in exploiting labor, the dignity of the human person can be jeopardized. Reciprocity or mutual benefit does not even get to the ears of capitalists, for they catapult it right away. It is disheartening to note that in any oligarchic system of economy, the exhaustion of natural resources and skills can demean and degrade human dignity. Accordingly, capitalism "reduces the world" and the human person "to raw things without intrinsic purpose and meaning," 47 and "demands that we slide solidarity to the side and agree to

\footnotetext{
${ }^{44}$ Ibid.

45 Taylor, Philosophy and Human Sciences, 307.

46 Taylor, The Pattern of Politics, 22.

${ }^{47}$ Taylor, "Solidarity."

https://www.kritike.org/journal/issue 21/cabunilas december2017.pdf
}

(C) 2017 Shierwin A. Cabunilas

ISSN 1908-7330

(c) BY-NC-ND 
bend or even break the rule of reciprocity in the name of effectiveness." 48 The sense of solidarity is dumped on the sidelines in the name of production and profit which further increases individualism. Capitalism can be characterized as predatory because the system of economic exchange is all about "relations of domination, of ownership of man by man." 49

However, capitalism will always be part of the structure of the society. People will always find themselves participating in economic exchanges. But this does not mean that nothing can be done about the negative aspect of capitalism. When capitalism is well-embedded in a decent regulatory system and framed according to principles of justice, it can also work to the advantage of society. Capitalism can be good if it does not "contradict the basic nature of law." 50 I understand this basic nature of law as pertaining to the distribution of resources and profits down to all members, thus reaching all sectors of the society. The basic needs such as healthcare, housing, quality education, just remuneration, and efficient transportation and communication facilities are some of the interesting examples of how market capitalism can be transformed through comprehensive democratic measures. Perhaps, these measures might also improve the treatment of human dignity among social actors.

In what way can market systems respond affirmatively to the thrust of the basic nature of law? This question seems difficult to answer considering the intricacies of the system of market economy. Taylor himself even acknowledges the difficulty of determining "the conditions of an advanced and progressive economy on a mass scale without also creating the conditions ... towards democratization." 51 I agree that creating the conditions for economic progress and democratization at the same time can be difficult. However, it does not seem to suggest that it is impossible. Incorporating economic planning into the overall goals of democratization might be a good solution. Specifically, this idea involves the restructuring of economic system through efficient and effective measures that are anchored in public policies which is oriented to a just society. The taxation system is an example of adequately managing the distribution of wealth. In this regard, capital gains, labor, inheritance, and properties must be reasonably taxed. It cannot be denied, however, that some political institutions hardly tax big corporations

${ }^{48}$ Charles Taylor, "Several Reflections on the Theme of Solidarity," trans. by Arthur Rosman, in Thinking in Values - The Tischner Institute of Journal of Philosophy 1 (2007), 75. Hereafter cited as "Several Reflections."

49 Taylor, Human Agency and Language, 89.

${ }^{50}$ Robert Dahl claims that in modern democratic societies, "market capitalism has not been abolished altogether," but "peacefully transformed by democratic means into far more humane and decent economic order." See Robert Dahl, "Justifying Democracy," in Society 35:2 (1998), 390.

${ }^{51}$ Taylor, The Pattern of Politics, 99.

(c) 2017 Shierwin A. Cabunilas

https://www.kritike.org/journal/issue 21/cabunilas december2017.pdf

ISSN 1908-7330

(cc) BY-NC-ND 


\section{ON DEMOCRATIZATION}

because they fear that these companies will leave and invest in another state that would only minimally, if not at all, require a tax from them. This exemption is unfair to the people who work so hard but pay heavy taxes.

A just and humane taxation system is needed, hence a restructuring of the taxation system. There is also a need for "a relatively strong commitment on the part of ... citizens" for "collective action" 52 to advance economic sustainability and distribution. The economic sphere is an avenue of solidaristic endeavor for a just and humane society. If the "economic pie" is utilized to meet the human predicaments, such as hunger, sickness, poverty, then the economic structures can be said to have satisfied the basic law of distribution of resources. On the other hand, if economic practices are not regulated by a just law, it can perpetuate a 'master-slave' relationship. Here, the economic structure forsakes and tramples human dignity. On the contrary, socioeconomic condition progresses best when people experience gradual relief from dreadful conditions.

But there is more to the law that must be satisfied. Economic practices should be anchored on mutual trust just as "democratic societies are based on trust." 53 Economic affairs must be tempered by mutual trust because it is vital in the overall conception of solidarity among diverse groups. A sense of trust drives away suspicion and establishes collective action. Of course, trust is something that is motivated by transparency, effective and responsible social welfare programs, and a just economic system. These measures beget trust from the people. For example, economic transparency can "bring the truth into the light and bring [it] into public consciousness." 54 It becomes an added motivation for people to cooperate collectively when there is transparency. Because they are aware of the socioeconomic realities that affect them, they can make the necessary adjustments and remedies and pass on important decisions. In the absence of transparency, it is likely that people will be at the losing end. Hence, an economic system betrays the trust of the people if it is devoid of humane and justice-oriented motivations. Betrayal refers to an outright negation of trust because it exploits the people by not giving them what they deserve for their output, and for using the output at the expense of others..$^{55}$

If there are no just laws, mutual trust and collective action that regulate the economy, the economic system might turn away from its social responsibility. Then, people would continue to be exploited when their dignity as "free and equal subjects" is not respected, and when what is due to them is not justly compensated. A regulated economy, however, is more

\footnotetext{
52 Taylor, Dilemmas and Connections, 90.

53 Taylor, "Several Reflections," 75.

${ }^{54}$ Ibid., 72.

${ }^{55}$ Ibid., 71.
}

(C) 2017 Shierwin A. Cabunilas

https://www.kritike.org/journal/issue 21/cabunilas december2017.pdf

ISSN 1908-7330

(c) $)$ BY-NC-ND 
advantageous to the weakest members of the society because their basic needs can be met.

With the above claims, it might be good to ask whether Taylor's economic advocacy is plausible. As noted, a just law, transparency, and mutual trust are regulating mechanisms which can preclude abuses and exploitations. I concur to this. However, these views are easier said than done. Consider the economic status of the Philippines. Although the Philippines is a democratic country, it is ironically a haven of oligarchs and influential politicians who apparently are preoccupied at amassing wealth at the expense of the population. They lord over the masses. Currently, the Philippines is dubbed "no longer the sick man of East Asia, but the rising tiger." This description, however, is a stark contrast of the real situation. The Philippines is suffering from a poor-rich divide disease. Philippines' economic gain, if there is, has not trickled down to the various sectors of the society, especially the marginalized. The state of the poor has not improved. Reports show that " 22 out of 100 families were estimated to be poor in the first semester of 2012 while 13 in 100 Filipinos lived in extreme poverty in the same period." ${ }^{56}$ Moreover, the National Statistical and Coordination Board forecasts that as of 2009 nationwide survey, "a total of 23.14 million Filipinos scrape by on 46.14 pesos (1.04 US dollars) a day or less." ${ }^{57}$

Some might point out that there are countries whose economic approach can be a source of inspiration if we apply a regulated capitalism scheme. The European Union is an example. One might say that the economy in most member states in the EU is not disentangled from its social responsibility because the wealth is distributed in many different forms: education, healthcare, research development projects, social security, infrastructures, etc. More so, the gains of the economy are not only distributed to its constituents but also to immigrants. The EU has reached this status, another would argue, because of the peoples' concerted effort to uphold a just law that can regulate socioeconomic processes and to ascertain mutual trust through a high degree of transparency. However, the EU has also suffered economic setbacks. Think of the economic crises in Greece and Spain respectively. Even if the EU can be said to have the most advanced liberal practices and economic systems, it is not immune to democratic deficits. Nonetheless, their experience can be a learning tool for democratizing societies and economies.

${ }^{56}$ Luis Bacani, "No improvements in the lives of poor Filipinos," in Philippine Star Global (23 April 2013) <http://www.philstar.com/business/2013/04/23/933989/no-improvement-livespoor-filipinos>.

57 Agence France-Presse, "One in 4 Filipinos live on a dollar a day," in Inquirer (8 February 2011), <http://globalnation.inquirer.net/cebudailynews/enterprise/view/20110208319235/One-in-4-Filipinos-live-on-dollar-a-day $>$.

(c) 2017 Shierwin A. Cabunilas

https://www.kritike.org/journal/issue 21/cabunilas december2017.pdf

ISSN 1908-7330

(cc) BY-NC-ND 


\section{Concluding Reflections}

In this paper, we analyzed Taylor's notions of identity and solidarity. Central to his view is building a just and humane society which, for him, should be the aim of democracy. A democratic society is anchored on a sense of belonging and meaning, strong allegiance to the state, and collaborative enterprise with the other members of the society. Seemingly this thrust has far-reaching and diverse implications insofar as questions of democratization are always contextually determined. One might argue that even though democracy does not have all the answers to sociocultural and politicoeconomic problems, it might still be the best civilized alternative approach because it provides opportunities for political and civic participation. Since democracy advocates "we-identities" such as collective action, sense of meaning, belonging, and real solidarity to the whole, "as against merely convergent I-identities," 58 it can redress the problem of indifference punctuated by atomistic and utilitarian doctrines. Commitment to political solidarity, for instance, can ignite the resolve of people towards a common goal. It can also enhance inter-subjective relations that have been wounded and clouded in animosity because of injustice. The social bond that democratic society nurtures can become "the engine of healing towards social action" which redresses, if not altogether eradicates, the injustice, discrimination, and exploitation of people..$^{59}$ Accordingly, the sense of social bond is inevitable for democracy and democratization.

Identifying with the political state expresses a commitment to collective and shared goods and shared goals. It presupposes the renunciation of atomistic views and sincerity to engage in a common enterprise, but it requires the freedom from "command-obedience" power structures because everything involuntary is not a practice of one's freedom..$^{60}$ To participate freely in charting the future of a democratic society can make it possible for every member to pursue a common objective. Apparently, for Taylor, this is an indispensable feature of political life and it is a tragedy for the society when "we cannot answer unconditionally"61 to it. Of course, solidaristic contestations will likely emerge because of the assertion of competing claims. However, they are also necessary for democratization as they can potentially rally political institutions toward a common purpose.

58 Charles Taylor, "The Dialogical Self," in Rethinking knowledge: reflection across the disciplines, ed. by Robert F. Goodman and Walter R. Fisher (USA: State University of New York Press, 1995), 192.

59 Taylor, "Several Reflections," 72.

60 Taylor, Philosophy and the Human Sciences, 192.

${ }^{61}$ Taylor, "Several Reflections," 73.

(C) 2017 Shierwin A. Cabunilas

https://www.kritike.org/journal/issue 21/cabunilas december2017.pdf

ISSN 1908-7330

(c) BY-NC-ND 
Indeed, it harnesses what I call twin approaches in democratization. These are ground-based and reflective approaches respectively.

The ground-based approach touches upon existing social conditions. It deals with the concrete concerns that society faces. A political institution is rooted in the factual realities of the people when it is not withdrawn from their concrete situations. Because it is grounded in real-life contexts, this ground-based approach can inform and aid legislations and public decisionmaking. The social context provides the necessary basis for charting and implementing policies that best respond to the people's concerns. Neglecting public affairs can lead to the creation of policies that are less effective in responding to the situation it is meant to address. Accordingly, inattention to facts precludes democratization.

The reflective approach refers to the rationalization aspect. It is crucial for any political community to evaluate and to assess the conditions affecting society. The reflective approach involves participation among the members of the political community to evaluate the available facts on the ground, to legislate relevant policies, and to visualize programs for collective action not only for the present but beyond. In short, the reflective approach is a sustained critical understanding of actual social conditions in lieu of creating policies that are suited to address them.

Appropriating both approaches can have the following advantages in mobilizing the democratization of society: (1) improve collective political action aimed at building a just and humane society, (2) preclude ineffective system that can potentially derail democratization, (3) provide avenues for greater political participation, enhancing the confidence of the people to exercise their shared sovereignty, (4) assist the people to vote for the right political leaders who can work with the interest of the society as a whole in mind, (5) adequately respond to current concerns, such as migration, climate change, environmental pollution and economic neoliberalism among others, and (6) reinforce mindfulness of effective and long-term development goals and not merely rely on short-term but costly and sometimes collaterally damaging solutions.

Of course, often the political directions of democratic societies have been put into question. For instance, one can even be skeptical whether democracy can manage twenty-first-century social problems, such as, political dynasty, oligarchy, unbridled corruption, climate change, refugee crisis, poverty, and hunger among others that tagged people along uncertain paths. Accordingly, there is no assurance that democracy can solve all the problems. Nonetheless, advancing the strengths and improving the limitations of a democratic system in the governance of public affairs can adequately pursue the case of a just and humane society. Democracy is still 
considered the best alternative government so far to realize this common project. Until then, the fate of the democratization of society is uncertain.

School of Philosophy, San Pablo Seminary, Baguio City, Philippines

\section{References}

Bacani, Luis, "No improvements in the lives of poor Filipinos," in Philippine Star Global (23 April 2013) <http://www.philstar.com/business 2013/04/23/933989/no-improvement-lives-poor-filipinos>.

Barth, Frederick, Introduction to Ethnic Groups and Boundaries: The Social Organization of Culture, ed. by Fredrik Barth (USA: Little, Brown and Company).

Bloemraad, Irene, "The Debate Over Multiculturalism: Philosophy, Politics, and Policy," in Migration Policy Institute (2011), $<\underline{\text { http://www.migrationinformation.org/Feature/display.cfm?ID }=854}$ $>$.

Commission for Social Development and Civil Society Forum, "Social Integration / Inclusion: Towards Societies of Solidarity and Mutuality," in United Nations - Department of Economic and Social Affairs, Division of Social Policy and Development (2009), $<$ http://www.un.org/esa/socdev/csd/2009/documents/csf/declaration .pdf $>$.

"Compendium of OFW Statistics (2005-2011)," in Philippine Overseas Employment Agency, <http://www.poea.gov.ph/ofwstat/compendium 2011.pdf>

Dahl, Robert, "Justifying Democracy," in Society 35:2 (1998).

Diola, Camila, "Singapore Leader defends Pinoys, labels 'spammers' a disgrace," in Philippine Star Global (21 April 2014), $<$ http://www.philstar.com/headlines/2014/04/21/1314411/singaporeleader-defends-pinoys-labels-spammers-disgrace $>$.

France-Presse, Agence, "One in 4 Filipinos live on a dollar a day," in Inquirer (8 February 2011), <http://globalnation.inquirer.net/cebudailynews Lenterprise/view/20110208-319235/One-in-4-Filipinos-live-on-dollara-day $>$.

Kymlicka, Will, "Multiculturalism: Success, Failure, and the Future," in Migration Policy Institute (February 2012), $<$ https://www.migrationpolicy.org/research/TCM-multiculturalismsuccess-failure>.

Smith, Nicholas H. and Arto Laitinen, "Taylor on Solidarity," in Thesis Eleven 99 (2009). 
Spinner-Halev, Jeff, "Democracy, Solidarity and Post-nationalism," in Political Studies 56 (2008).

Taylor, Charles, Dilemmas and Connections: Selected Essays (USA: Harvard University Press, 2011). - Human Agency and Language: Philosophical Papers 1 (USA: Cambridge University Press, 1985). "Interculturalism or Multiculturalism," in Philosophy and Social Criticism 38 (2012). Modern Social Imaginaries (Durham and London: Duke University Press, 2004). Philosophical Arguments (USA: Harvard University Press, 1995). Philosophy and Human Sciences: Philosophical Papers 2 (USA: Cambridge University Press, 1985). "Several Reflections on the Theme of Solidarity," trans. by Arthur Rosman, ub Thinking in Values - The Tischner Institute of Journal of Philosophy 1 (2007). "Solidarity in a Pluralist Age," in Project Syndicate (2010) $<$ http://www.project-syndicate.org/commentary/solidarity-in-apluralist-age $>$.

"The Dialogical Self," in Rethinking knowledge: reflection across the disciplines, ed. by Robert F. Goodman and Walter R. Fisher (USA: State University of New York Press, 1995).

The Dynamics of Democratic Exclusion," in Journal of Democracy 9:4 (1998).

The Other and Ourselves: Is Multiculturalism Inherently Relativists?" in Project Syndicate (19 July 2002), < https://www.projectsyndicate.org/commentary/the-other-and-ourselves--is-multiculturalism-inherently-relativist?barrier=accessreg $>$.

, The Pattern of Politics (Toronto: The Canadian Publishers, 1970).

"The Politics of Recognition," in Multiculturalism: Examining the Politics of Recognition, ed. by Amy Gutmann (Princeton: Princeton University Press, 1994).

Taylor, Charles and Slawomir Sierakowski, "The de-politicization of politics," in Eurozine (10 November 2011) <http://www.eurozine.com Larticles/2011-11-10-sierakowski-en.html>.

UNESCO, "Universal Declaration on Cultural Diversity," in United Nations Human Rights - Office of the High Commissioner (2001), $<$ http://www.ohchr.org/EN/ProfessionalInterest/Pages/CulturalDive rsity.aspx>. 